\title{
The Influence of Corporate Social Responsibility (CSR) Disclosure and Sustainability Accounting on Earnings Response Coefficient (ERC)
}

\author{
Addam Baskoro ${ }^{1}$, Haryono Umar ${ }^{2}$, Agustina Indriani ${ }^{3}$ \\ 1,2Perbanas Institute, Jakarta \\ ${ }^{3}$ Darma Persada University, Jakarta
}

\begin{abstract}
The research aimed to analyze the factors which provide earning response coefficient (ERC) received by automotive manufacturing companies listed on the Indonesia Stock Exchange using indicators of corporate social responsibility (CSR) and sustainability accounting from 2013 through 2017. The purposive sampling technique was used to gather data with the criteria, according which 13 companies were obtained as samples, (1) automotive manufacturing companies in 2013 - 2017 listed on the Indonesia Stock Exchange (IDX) (2) automotive manufacturing companies that published the annual reports. Meanwhile, the data were obtained from IDX \& published annual reports. The research used a panel data regression panel and data regression model as the analysis technique. The analysis consists of three methods, namely common effect method, fixed-effect and random effect, while the hypothesis testing used t-statistics to test partial regression coefficients and f statistics to test the effect simultaneously at the significance level of 5\%. Eventually, the results of the analysis used E-views to show whether: (1) corporate social responsibility (CSR) influences the earnings response coefficient (ERC) and (2) sustainability accounting influences the ERC. The T-test analysis results used E-views to reveal whether CSR and sustainability accounting influence ERC in automotive manufacturing companies listed on the IDX in $2013-2017$.
\end{abstract}

KEYWORDS: Corporate Social Responsibility (CSR), Earnings Response Coefficient (ERC), Sustainability Accounting

\section{INTRODUCTION}

Companies are required to disclose their corporate social responsibility activities to the communities. Such disclosure is a potential factor to create regulation in informing corporate financial statements in the capital market in line with corporate social responsibility activities which can become information for stakeholders. Therefore, the capital market is a major driving factor for disclosing corporate social responsibility.

Both financial and annual reports provide information that must be officially published. The published data must reveal the actual financial condition so that investors can find out the accounting profit the company earns. An indicator used to measure investors' reactions to accounting earnings information is the earnings response coefficient (ERC). The coefficient is used as an alternative measure to determine earnings information's value relevance.

In recent years, Indonesia's automotive manufacturing sector still indicated a low figure below 5\%. Attention should be taken so that the difference in return received is not greater than the expected return value. Therefore, to improve the quality of the company earnings, there are several influencing factors on ERC, such as corporate social responsibility (CSR) and sustainability accounting.

By the implementation of CSR, it is expected that the company will gain social legitimacy and maximize its financial strength in the long term. Sustainability accounting or sustainability report also links to the earnings response coefficient (ERC). It is a technique for measuring, disclosing, and taking accountability for organizational performance in achieving sustainable development to stakeholders. Based on previous researches, it is necessary to conduct a research which investigates the effect of corporate social responsibility (CSR) disclosure and sustainability accounting on earnings response coefficient (ERC). For the purpose, this empirical study was conducted on automotive manufacturing companies listed on the Indonesia Stock Exchange in 2014-2018.

\section{LITERATURE REVIEW}

Corporate social responsibility (CSR) (X1) is a company or business world's commitment to contribute to sustainable economic development by paying attention to and bearing responsibility for the social environment and emphasizing balancing the concern between economic, social, and environmental aspects. 


\section{International Journal of Current Science Research and Review}

ISSN: 2581-8341

Volume 04 Issue 07 July 2021

DOI: 10.47191/ijcsrr/V4-i7-10, Impact Factor: 5.825

IJCSRR@ 2021

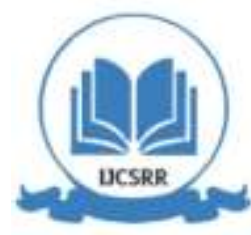

www.ijcsrr.org

On the other hand, sustainability accounting (X2) is a sub-category of financial accounting that focuses on disclosing information on the organization's non-financial performance to stakeholders. This performance includes activities that directly impact society, the environment, and the economy. Furthermore, the earnings response coefficient (ERC) (Y) estimates changes in the company's stock price as a result of its earnings information announced to the market.

\subsection{Disclosure of Corporate Social Responsibility}

According to Max Caldwell (2014:79), CSR is an aspect that strengthens the level of employee engagement in an organization. This idea was put forward based on previous findings where CSR is one of the 18 triggers for employee engagement (Towers Perrin, n.d). MBR (2009). Furthermore, it lists specific benefits from involving employees in the CSR programs, such as to adhere the employees to the organization's vision and mission, increase their expertise/skills and provide them opportunities to gain new skills. This study reveals corporate social responsibility in a company's annual report as indicated with the corporate social responsibility disclosure index (CSRI). The study used the CSRI measurement instrument based on the GRI indicators (G3), classified CSR information into several categories, i.e. economy, environment, labor, human rights, social, and products. Meanwhile, the GRI (Global Reporting Initiative) is an official institution that issues sustainability reporting standards. A dichotomous approach to calculate CSRI, which implement that each CSR item of the research instrument is assigned a value of 1 whenever it is disclosed and 0 if it is not (Haniffa et al., 2014: 33). Next, each item's scores are summed up to obtain the overall score for each company. The CSRI calculation formula is as follows:

$$
\operatorname{CSRI}_{j}=\frac{\sum X_{i j}}{n_{j}}
$$

Where:

CSRIj is corporate social responsibility disclosure index of company $\mathrm{j}, \mathrm{Nj}$ is the number of a company $\mathrm{j}$ items, $\Sigma \mathrm{Xij}$ is dummy variable, $1=$ if the item $\mathrm{i}$ disclosed; $0=$ if the item $\mathrm{i}$ not disclosed. Therefore, $0 \leq \mathrm{CSRIj} \leq 1$.

\subsection{Sustainability accounting}

According to Elkington (2010), sustainability report (SR) has various definitions. SR refers to a report that contains not only financial performance but also non-financial information consisting of information on social and environmental activities that enable companies to grow sustainably (sustainable performance). On the other hand, according to Heemskerk, Pistorio and Scicluna (2002:7), a sustainability report is defined as public reports by companies to provide internal and external stakeholders with a picture of corporate position and activities on economic, environmental and social dimensions. In short, such reports attempt to describe the company's contribution to sustainable development.

Sustainability accounting or also known as social accounting, social and environmental accounting, corporate social reporting, corporate social responsibility reporting, or non-financial reporting is a sub-category of financial accounting focusing on disclosure of organizational non-financial performance information to stakeholders. The performance encompasses activities that directly impact society, the environment, and the economy. Sustainability accounting contrasts to management accounting which focuses on decision making and internal policies (Dally, 2011:8).

In sustainability accounting, one of the main challenges includes a lack of understanding of the precise definition of 'sustainable development'. According to Brundland (2010:78), sustainable development refers to that which meets present needs without compromising the ability of future generations to meet their own needs. This is to raise questions about the extent of our own needs and those of future generations. As such, it is difficult to explain the relationship between time and geography between the triangles of organization, environment and social impacts. For example, how far the environmental account in a company can guarantee the benefit of the environment and how significant a portion of its role is in saving the future.

More specifically, sustainability reports are proxied by the SRDI (sustainability report disclosure index) which is performed by assigning a value of 1 if the item is disclosed or 0 if not disclosed. Then all scores are summed up as a whole. After scoring each index, the value is calculated with the SRDI formula as follows:

$$
\mathrm{SRDI}=\frac{\mathrm{n}}{\mathrm{k}}
$$

Where:

SRDI is sustainability report disclosure index, $\mathrm{N}$ is the number of company's samples, and $\mathrm{K}$ refers to the number of classes. 


\section{International Journal of Current Science Research and Review}

ISSN: 2581-8341

Volume 04 Issue 07 July 2021

DOI: 10.47191/ijcsrr/V4-i7-10, Impact Factor: 5.825

\subsection{Earning response coefficient (ERC)}

Good earnings quality can be determined using ERC as a measuring tool of the earnings information content. In this study, the ERC estimate is a coefficient obtained from cross-sectional regression between cumulative abnormal return (CAR) as a proxy for stock prices and unexpected earning (UE). Furthermore, CAR is obtained using a window (time interval), in which, the CAR is calculated daily for 15 months from 1 January to 31 March. It is because that too short period used will not be able to show market reactions that may occur outside the time interval. For example, it is due to the slow reaction of investors. On the other hand, when the period used is too long, it can provide a biased measurement regarding the company's contribution of information disclosure.

In this study, to calculate the abnormal return in 2013, it used the company's stock price and the composite stock price index during the period 1 January 2013 to 31 March 2014. Meanwhile, to calculate the abnormal return in 2014, it used the company's stock price and the composite stock price index from 1 January 2014 to 31 March 2015 onwards until 2017.

The calculation of abnormal return in this study used market-adjusted models which assumes that the market index return is the best measurement (Pincus in Widiastuti, 2012). Therefore, it is unnecessary to use the estimation period to form an estimation model since the estimated securities return is the same as the market index return in the period. As such, the market return index uses the return from the composite stock price index (IHSG). The calculation of the abnormal return can be performed using the following formula.

\section{$\mathbf{C A R}=\boldsymbol{\Sigma} \mathbf{A R}_{\mathrm{it}}$}

$$
\begin{aligned}
& R_{i t}=\frac{\text { Pit }- \text { Pit }-1}{\text { Pit }-1} \\
& R_{m r}=\frac{\text { IHSGt }-1 H S G t-1}{I H S G t-1} \\
& \mathrm{AR}_{i t}=\mathrm{R}_{i t}-\mathrm{R}_{m t}
\end{aligned}
$$

Where:

ARit is abnormal return for company $\mathrm{i}$ on day $\mathrm{t}$

Rit is daily return of company $i$ on day $t$

Rmt: the market index return on the day $\mathrm{t}$

Pit: the share price of company $i$ on day $t$

Pit-1: the share price of company $i$ on day $t-1$

IHSGt: composite stock price index at time $\mathrm{t}$

IHSGt-1: composite stock price index at $\mathrm{t}-1$

Meanwhile, unexpected earning (EU) is determined as the change in earnings per share of the company before extraordinary items for the current year deducted by earnings per share before extraordinary items in the previous year and scaled at a price per share at the end of the previous period (Kothari \& Zimmerman in accounting implemented to accounting earnings (Widiastuti, 2010:93-94). According to Widiastuti (2010:112), accounting earnings per share indicates internal performance, while stock prices indicate market performance. The EU is calculated using the following formula.

$$
\mathrm{UE}_{i t}=\frac{E i t-E i t-1}{|E i t-1|}
$$

Where:

UEit: unexpected earning of company $i$ in period $t$

Eit: earnings per share of company $i$ in period $t$

Eit-1: earnings per share of company $i$ in period $t-1$

\subsection{Hypothesis development}

2.4.1 Corporate social responsibility (CSR) is closely related to the earnings response coefficient (ERC). It means that companies which have well carried out CSR programs will have positive views from investors and the public. Thus, it can affect the amount 


\section{International Journal of Current Science Research and Review}

ISSN: 2581-8341

Volume 04 Issue 07 July 2021

DOI: 10.47191/ijesrr/V4-i7-10, Impact Factor: 5.825

IJCSRR@ 2021

Www.ijcsrr.org

of profit/return they will earn. For instance, a research conducted by Fitriani (2012) showed positive results of CSR on ERC.

H1: corporate social responsibility (CSR) positively influences the earnings response coefficient (ERC).

2.4.2. Through sustainability accounting disclosure in the annual report, investors can recognize the company's performance and can determine the earnings response coefficient (ERC). This performance includes activities that directly impact society, the environment, and economy. A research conducted by Juwita (2017) revealed the results that there was a positive influence of sustainability accounting on ERC.

H2: Sustainability accounting has a positive effect on earnings response coefficient (ERC)

2.4.3 Earnings response coefficient (ERC) is closely related to disparate market responses to the relationship between earnings and security returns. Previous empirical studies have been conducted to measure whether corporate social responsibility (CSR) and sustainability accounting influence the earnings response coefficient (ERC). However, these studies obtained different results, either supporting or contradicting this study's hypothesis. For instance, a research conducted by Yosefa (2012) revealed that there is a positive effect of CSR and sustainability report and on ERC.

H3: corporate social responsibility (CSR) and sustainability accounting positively affect the earnings response coefficient (ERC).

\section{METHODOLOGY}

It is quantitative research with a scope limited to corporate social responsibility (CSR), sustainability accounting and earnings response coefficient (ERC) in automotive manufacturing companies listed on the Indonesia Stock Exchange (IDX). The data were gathered from the corporate social responsibility report and the annual report from 2014 to 2018.

The population in this study only comprised automotive manufacturing companies, the criteria of which were taken into consideration as follows: (1) listed on the Indonesia Stock Exchange (BEI) 2014 - 2018, (2) issue annual report, (3) publish the corporate social responsibility report in the annual report. Based on the above criteria, the sample size was 13 companies. Quantitative analysis methods can be tested using statistical testing, i.e. regression models with panel data as a combination of cross-section and time-series data.

\section{RESULTS AND DISCUSSIONS}

Regression analysis on panel data was carried out using the fixed effect estimation model. The test aims to estimate the fixed effect model panel data to capture the intercept differences between variables. The intercept differences might occur due to different data originating from panel data.

4.1 Panel data regression analysis

Table 4.1 Panel data regression analysis

Dependent variable: ERC

Method: Panel Least Squares

Date: 14/01/20 Time: 18:46

Sample: 2014-2018

Periods included: 5

Cross-sections included: 13

Total panel (balanced) observations: 65

\begin{tabular}{lllll}
\hline \hline Variable & Coefficient & Std. Error & t-Statistic & Prob. \\
\hline \hline C & 0.545908 & 0.846329 & 7.473289 & 0.0000 \\
CSR & 0.590392 & 0.743813 & 5.984072 & 0.0021 \\
Sustainability & 0.469171 & 0.579811 & 5.798374 & 0.0008 \\
Fixed Effects (Cross) & & & & \\
\hline \hline
\end{tabular}

Effect Specification 


\section{International Journal of Current Science Research and Review}

ISSN: 2581-8341

Volume 04 Issue 07 July 2021

DOI: 10.47191/ijcsrr/V4-i7-10, Impact Factor: 5.825

IJCSRR@ 2021

www.ijesrr.org

Cross-section fixed (dummy variables)

$\begin{array}{llll}\text { R-squared } & 0.447583 & \text { Mean dependent var } & 0.543728 \\ \text { Adjusted R-squared } & 0.464178 & \text { S.D. dependent var } & 0.661649 \\ \text { SE of regression } & 0.517974 & \text { Akaike info criterion } & 0.563292 \\ \text { Sum squared resid } & 1.374618 & \text { Schwarz criterion } & 0.618964 \\ \text { Log likelihood } & 47.41372 & \text { Hannan-Quinn criter } & 0.018966 \\ \text { F-statistic } & 18.64896 & \text { Durbin-Watson stat } & 1.748966 \\ \text { Prob(F-statistic) } & 0.000000 & & \end{array}$

Source: eviews 10 output

To determine whether there is the influence of corporate social responsibility (CSR) and sustainability accounting on the earnings response coefficient (ERC), a panel data regression analysis was carried out. The results of data processing using the fixed-effect method follows the formula:

$$
Y=0.545908+0.590392 X_{1}+0.469171 X_{2}+e
$$

Where:

$\mathrm{Y}=$ earning response coefficient (ERC)

$\mathrm{X}_{1}=$ corporate social responsibility $(\mathrm{CSR})$

$\mathrm{X}_{2}=$ sustainability accounting

Based on the above equation, it could be drawn several conclusions as follows:

1. The constant value in this study is 0.545908 , by which, if the value of corporate social responsibility (CSR) and sustainability accounting is equal to 0 , the value of earning response coefficient (ERC) is 0.545908 .

2. The regression coefficient for corporate social responsibility (CSR) is 0.590392 , indicating that if the value of corporate social responsibility (CSR) increases by 1 point. In contrast, the other variables are constant, the earnings response coefficient (ERC) value will increase by 0.590392 , and vice versa.

3. The regression coefficient of sustainability accounting is 0.469171 , indicating that if the sustainability accounting increases by 1 point while the other variables are constant, the earnings response coefficient (ERC) value will increase by 0.469171 , and vice versa.

\subsection{Hypothesis testing}

\subsubsection{Test of the coefficient of determination $\left(R^{2}\right)$}

The coefficient of determination test was carried out to determine the extent to which the relationship among the variables, i.e. corporate social responsibility (CSR) and sustainability accounting on the earning response coefficient (ERC), exists. The method is to square the correlation coefficient value and then transform it to a percentage. The result of determination coefficient processed using EViews 10.0 is as follows:

\section{Adjusted R-squared $=\mathbf{0 . 4 6 4 1 7 8}$}

The result of the determinant coefficient test based on adjusted $\mathrm{R}$ square is 0.464178 or $46.41 \%$, while the standard error value of the regression model is 0.517974 , as indicated with the label 'SE of regression'. This standard error value is less than that of the standard deviation of the response variable, which is indicated with the label 'SD dependent var' equal to 0.661649. It means that the regression model is valid as a predictor model. Thus, the fluctuating value of the earnings response coefficient (ERC) variable in automotive manufacturing companies for 2014 - 2018 used as the research object can be explained by independent variables, i.e. corporate social responsibility (CSR) sustainability accounting. Thus, the other factors as much as $54.59 \%$ are influenced by other variables outside this study's scope.

\subsubsection{Simultaneous test (F-Test)}

The F test was carried out to observe whether the model being analyzed has a high level of model feasibility, i.e. the variables used by the model can explain the model being analyzed and also to find out whether there is a simultaneous effect among the variables 


\section{International Journal of Current Science Research and Review}

ISSN: 2581-8341

Volume 04 Issue 07 July 2021

DOI: 10.47191/ijcsrr/V4-i7-10, Impact Factor: 5.825

IJCSRR@ 2021

www.ijcsrr.org

of the automotive manufacturing company in $2014-2018$ on the earnings response coefficient (ERC).

Table 4.2 Effect of corporate social responsibility (CSR) and sustainability accounting variables on earnings response coefficient (ERC) in automotive manufacturing companies in $2014-2018$

\begin{tabular}{llll}
\hline \hline R-squared & 0.447583 & Mean dependent var & 0.543728 \\
Adjusted R-squared & 0.464178 & S.D. dependent var & 0.661649 \\
SE of regression & 0.517974 & Akaike info criterion & 0.563292 \\
Sum squared resid & 1.374618 & Schwarz criterion & 0.618964 \\
Log likelihood & 47.41372 & Hannan-Quinn criter & 0.018966 \\
F-statistic & 18.64896 & Durbin-Watson stat & 1.748966 \\
Prob(F-statistic) & 0.000000 & & \\
\hline \hline
\end{tabular}

Source: output of eviews 10

The F-count value is 18.64896 , which is greater than that of F-table 2.87, while the probability value (F-statistic) is 0.000000 . Using the degree of error at $\alpha=5$ per cent or 0.05 , the probability (F-statistic) is less than 0.05 . It indicates that there is an effect of variables of corporate social responsibility (CSR) and sustainability accounting on earnings response coefficient (ERC) in automotive manufacturing companies in 2014 - 2018. The fluctuation of the earnings response coefficient (ERC) variable in automotive manufacturing companies in 2014 - 2018 can be explained by independent variables (corporate Social responsibility and sustainability accounting). Therefore, other factors account for $54.59 \%$.

\subsubsection{Partial test (t-test)}

The t-test (partial regression test) was conducted to determine whether corporate social responsibility (CSR) and sustainability accounting influence the earnings response coefficient (ERC) if the $t$-count is at sig $<0.05$. Using coefficients analysis with Eviews processing, The t-test obtains the following results.

Table 4.3 Effect of variable corporate social responsibility and sustainability accounting on earnings response coefficient (ERC) in automotive manufacturing companies during $2014-2018$

\begin{tabular}{lcccc}
\hline \hline Variable & Coefficient & Std. Error & t-Statistic & Prob. \\
\hline \hline C & 0.545908 & 0.846329 & 7.473289 & 0.0000 \\
CSR & 0.590392 & 0.743813 & 5.984072 & 0.0021 \\
Sustainability & 0.469171 & 0.579811 & 5.798374 & 0.0008 \\
\hline \hline
\end{tabular}

Source: the output of eviews 10

a) Variable of corporate social responsibility (CSR), we obtained the results of t-count 5.984072>t-table 1.72472 in a probability value of 0.0021 greater than that of the significance level 0.05 . Therefore, the hypothesis is accepted; in other words, corporate social responsibility (CSR) positively influences earnings response coefficient (ERC). The regression coefficient of corporate social responsibility (CSR) is 0.590392 , indicating that if CSR's value increases by 1 point while the other variables are constant, the value of the earning response coefficient (ERC) will increase 0.590392 , and vice versa.

b) Variable of sustainability accounting, the t-count result is 5.798374> t-table, i.e. 1.72472 in a probability value of 0.0008 , which is less than the significance level of 0.05 . Therefore, the hypothesis is accepted; in other words, sustainability accounting has a significantly positive influence on the earnings response coefficient (ERC). The regression coefficient of sustainability accounting is 0.469171 , indicating that if the value of sustainability accounting increases by 1 point while the other variables are constant, the value of earning response coefficient (ERC) will increase by 0.469171 , and vice versa. 


\section{International Journal of Current Science Research and Review}

ISSN: 2581-8341

Volume 04 Issue 07 July 2021

DOI: 10.47191/ijcsrr/V4-i7-10, Impact Factor: 5.825

IJCSRR@ 2021

Www.ijcsrr.org

\section{CONCLUSIONS}

Based on our study findings and discussions above, there are some conclusions as follows:

1. The first research objective results in that there is an influence of corporate social responsibility (CSR) on earnings response coefficient (ERC) in automotive manufacturing companies listed on the Indonesia Stock Exchange in 2014 - 2018.

2. The second objective of the study reveals that there is an influence sustainability accounting variable on the earnings response coefficient (ERC) in automotive manufacturing companies listed on the Indonesia Stock Exchange in 2014 - 2018.

3. The third objective of the study shows that there is a simultaneous influence of corporate social responsibility (CSR) and sustainability accounting on earnings response coefficient (ERC) in automotive manufacturing companies listed on the Indonesia Stock Exchange in $2014-2018$.

\section{REFERENCES}

1. Hendrik, Budi Untung. 2009. Corporate Social Responsibility. Jakarta: Sinar Grafika.

2. Murray, Robert K, et al. 2006. Biokimia Harper ed. 25. Jakarta: EGC. P.236-239

3. Naimah, Zahroh dan Utama, Siddharta. 2008. Pengaruh Ukuran Perusahaan, Pertumbuhan, dan Profitabilitas Perusahaan terhadap Koefisien Respon Laba dan Koefisien Respon Buku Ekuitas: Studi pada Perusahaan Manufaktur di Bursa Efek Indonesia. Artikel yang Dipresentasikan pada Simposium Nasional Akuntansi IX Padang tanggal 23-26 Agustus 2008

4. Beaver, William H. 1968. The Information Content of Annual Earning Releases : A Trading Volume Approach. Supplement to journal of Accounting Research, hal 67-92.

5. Amir, E., dan Baruch Lev. 1999. "Value-relevance of non-financial information: The wireless communications Industry". Journal of Accounting and Economics 22, hal. 2-30

6. Murwaningsari, Etty. 2009. Hubungan Corporate Governance, Corporate Social Responsibilities dan Corporate Financial Performance Dalam Satu Continuum. Jurnal Akuntansi dan Keuangan. Vol. 11. No. 1, 30-41

7. Sharma, H. C., Kiran K. S., Nadoor S., and Rodomiro O.. 2000. Prospects for Transgenic Resistance to Insects. Electronic J Biotechnology.

8. Blowfield, M. and Murray, A. (2008) Corporate Social Responsibility: A Critical Introduction. New York: Oxford University Press

9. Cahyanti Dwi Putri, Merysha. (2013). Komunikasi Organisasi, dan omitmen Organisasi Pengaruhnya Terhadap Kepuasan Kerja di Perusahaan Pusair Bandung

10. Barus, Riantri dan Maksum Azhar. (2011). Analisis Pengungkapan Informasi Corporate Social Responsibility dan Pengaruhnya Terhadap Return Saham. Vol. 15, No. 1. Retrieved from Jurnal Akuntansi dan Auditing Indonesia.

11. Kotler dan Keller, (2012:27). Manajemen Pemasaran edisi ketigabelas jilid 1 dan 2 dialihbahasakan oleh Bob Sabran, Jakarta: Erlangga

12. Haryudanto, Danang. 2011. "Pengaruh Manajemen Laba Terhadap Tingkat Corporate Social Responsibility dan Nilai Perusahaan". Unpublished Skripsi. Semarang: Universitas Diponegoro. Diperoleh tanggal 15 April 2014.

13. Cahyono, Budi. (2011). Pengaruh Corporate Social Responsibility Terhadap Kinerja Perusahaan Dengan Kepemilikan Asing Sebagai Variabel Moderating: Studi Empiris pada Perusahaan Manufaktur yang Terdaftar di Bursa Efek Indonesia. Unpublished Skripsi, Semarang: Universitas Diponegoro.

14. Syafrudin, M. 2012. Pengaruh Ketidaktepatwaktuan Penyampaian Laporan Keuangan pada Earnings Response Coefficient: Studi di BEJ. Simposium Nasional Akuntansi VII: 754-765.

15. Givoly, Hayn. 2000. The changing time properties of earning cash flow and accruals. Journal of accounting \& Economics.

16. Millatina, Dini. (2012). Analisis Pengaruh Kandungan Informasi Komponen Laba dan Rugi Terhadap ERC (Studi Empiris pada Perusahaan Manufaktur yang Terdaftar di Bursa Efek Indonesia). Unpublished Skripsi, Semarang: Universitas Diponegoro.

17. Santoso, S. 2010. Statistik Parametik. Jakarta: PT Elex Media Komputindo.

18. Sekaran, Uma. 2006. Research Methods For Business. Jakarta. Peneribit Salemba

19. Sugiyono. (2013). Cara Mudah Menyusun Skripsi,Tesis,dan Disertasi. Bandung: CV Alfabeta. 


\section{International Journal of Current Science Research and Review}

ISSN: 2581-8341

Volume 04 Issue 07 July 2021

DOI: 10.47191/ijcsrr/V4-i7-10, Impact Factor: 5.825

IJCSRR@ 2021

www.ijcsrr.org

20. Widiyanto, Andi. (2016). Analisis Tingkat Kesehatan Bank Dengan Menggunakan Metode Risk Based Bank Rating (RBBR) (Studi pada Bank Yang Terdaftar Di Bursa Efek Indonesia Dalam IHSG Sub Sektor Perbankan Tahun 2012 2014). Jurnal Ekonomi dan Bisnis Vol 8 No 2.

21. Yuzi, Aida., \& Lau, Wee-Yeap. (2016). A Critical Analysis of The Malaysian Risk-Based Capital Framework: A Comparison Between General Insurance and Takaful. Journal of Institutions and Economies Vol 8 No 4

Cite this Article: Addam Baskoro, Haryono Umar, Agustina Indriani (2021). The Influence of Corporate Social Responsibility (CSR) Disclosure and Sustainability Accounting on Earnings Response Coefficient (ERC). International Journal of Current Science Research and Review, 4(7), 684-691 